\title{
Itinerari de recerca geològica per la comarca del Baix Llobregat: des de la Puda, a Sant Salvador de les Espases, al coll de Can Tobella i al Cairat
}

Josep Maria Mata-Perelló

Joaquim Sanz Balagué

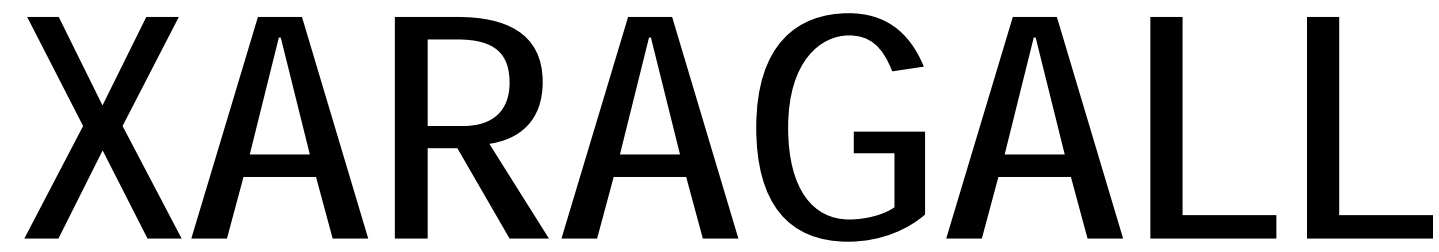

REVISTA DE CIÈNCIES DE LA CATALUNYA CENTRAL n. 5

MAIG 2014 


\title{
ITINERARI DE RECERCA GEOLÒGICA PER LA COMARCA DEL BAIX LLOBREGAT: DES DE LA PUDA, A SANT SALVADOR DE LES ESPASES, AL COLL DE CAN TOBELLA I AL CAIRAT
}

\author{
Josep Maria Mata-Perelló \\ Museu de geologia Valentí Masachs, Escola Politècnica Superior d'Enginyeria de Manresa \\ (EPSEM), Universitat Politècnica de Catalunya · BarcelonaTech (UPC), 08272 Manresa, Spain
}

\section{Joaquim Sanz Balagué}

Departament d'Enginyeria Minera i Recursos Naturals (EMRN), Escola Politècnica Superior d'Enginyeria de Manresa (EPSEM), Universitat Politècnica de Catalunya . BarcelonaTech (UPC), 08272 Manresa, Spain

Paraules clau: Serralada prelitoral catalana; Paleozoic; Mesozoic; Patrimoni Geològic

\section{Resum}

Itinerari realitzat el 21 d'abril de 2013. En aquesta ocasió, aquest recorregut transita íntegrament per la zona de contacte entre dues de les unitats geològiques que constitueixen el nostre país; concretament entre el Sistema Mediterrani i la Depressió Geològica de l'Ebre. Tot i així, la major part del recorregut transitarà per la primera unitat geològica esmentada.

Així, el recorregut s'iniciarà a la Serralada Prelitoral Catalana (ubicada dintre de la primera unitat geològica abans esmentada, el Sistema Mediterrani), per a finalitzar de nou a aquesta unitat geològica, després de transitar durant bona part del recorregut per la segona, per la Depressió Geològica de I’Ebre.

Per d'altra banda, el recorregut discorrerà per una de les comarques que constitueixen la Regió de Barcelona: concretament per la del Baix Llobregat (pel terme d'Esparreguera, exclusivament). 


\section{Objectius fonamentals}

Els objectius fonamentals d'aquest itinerari es centraran en els següents aspectes:

1. Observació de l'estructura de la Serralada Prelitoral Catalana, per la qual discorrerà el recorregut del present itinerari, en la seva major part, entre la Puda i el Cairat; així com dels recorreguts que es faran, especialment pel camí que remunta el torrent de la Frau, pujant a Sant Salvador de les Espasses.

2. Observació dels materials paleozoics (de l'Ordovicià i del Silurià) i dels mesozoics (del diferents trams del Triàsic), els quals constitueixen la Serralada Prelitoral Catalana, pels indrets on discorrerà el recorregut de l'itinerari.

3. Observació de l'estructura de la Depressió Geològica de l'Ebre, per la qual transitarà I'itinerari als darrers trams del recorregut, especialment pels voltants del Cairat, Sant Salvador de les Espasses i de Can Tobella, entre altres indrets.

4. Observació dels materials cenozoics (del Paleocè i de I’Eocè), que constitueixen la Depressió Geològica de I'Ebre, per aquests indrets per on discorre l'itinerari. Aquests materials, pertanyen fonamentalment a la Formació Mediona i a la Formació Cairat.

5. Observació de les relacions estructurals entre les tres unitats geològiques acabades d'esmentar, com els encavalcaments de Triàsic sobre els materials cenozoics, que veurem pels voltants del viaducte del Cairat.

6. Observació dels diferents indrets relacionats amb el Patrimoni Geològic i amb el Patrimoni Miner, que anirem trobant al llarg del recorregut del present itinerari.

\section{Antecedents bibliogràfics}

Ens referirem a l'antecedent més pròxim, el qual és quelcom antic. Es tracta de Mata-Perelló (1984). Més recents són altres treballs nostres com: Mata-Perelló (2001, 2005, 2012a, 2012b i especialment 2013, coincident en part amb aquest que ara presentem).

Altres antecedents cal buscar-los als treballs següents: Calzada (1977), Llopis Lladó (1974), Marzo i Anadón (1977), Masachs (1981), Soler (1982) I Virgill (1858). Tots ells són de caràcter geològic. Tanmateix, cal fer esment del nostre treball: Mata-Perelló i Climent Costa (2010), dedicat íntegrament al coneixement de la geologia de la comarca del Baix Llobregat.

Dintre de l'apartat dedicat a les referencies bibliogràfiques ja ens referirem a tots ells.

\section{Recorregut de l'itinerari}

Com ja s'ha dit anteriorment, aquest itinerari discorrerà exclusivament pel terme municipal d'Esparreguera, que pertany a la comarca del Baix Llobregat. I cal dir que es passarà indrets llunyans a la capçalera municipal.

Així, el recorregut s'iniciarà per les immediacions de la Puda. A partir d'aquest indret s'anirà cap a Sant Salvador de les Espasses, cap a las immediacions de Can Tobella, fins arribar a les immediacions del Cairat, per on finalitzarà el recorregut de l'itinerari. 


\section{Advertiment previ}

En aquest itinerari (a l'igual que a d'altres itineraris geològics...) es realitzaran diverses aturades, les quals consistiran en la descripció de diferents aspectes geològics i mineralògics.

El recorregut d'aquest itinerari es realitzarà totalment a peu, per diferents indrets del terme municipal d’Esparreguera, de la comarca del Baix Llobregat, especialment pels voltants de la Puda de Montserrat.

A l'igual que als altres itineraris realitzats fins ara, recomanem tenir la màxima cura de respecte cap al Medi Natural i cap al Medi Ambient al llarg de tot el recorregut, i també fora d'ell.

\section{Descripció de l'itinerari}

Com en altres recorreguts, es realitzaran una sèrie de parades (aturades o estacions). En cada cas, s'efectuaran diverses observacions de caràcter geològic. Al respecte, en cada cas, $s$ 'indicarà el municipi i la comarca on es troba l'aturada. També s'indicarà el numero del mapa (a escala 1:50.000) on es troba ubicada la parada, que normalment serà el 392 (o full de Sabadell). Aquest full és dels editats per I'Instituto Geográfico y Catastral de España. Així doncs, la relació d'aquestes aturades, d'acord amb el seu ordre dintre del recorregut, serà el següent:

\subsection{Parada 1. Immediacions de l'inici de la carretera local al balneari de la Puda, (terme municipal d’Esparreguera, comarca del Baix Llobregat, subcomarca del Baix Llobregat - Nord). (Full 392)}

Tot i que el recorregut de l'itinerari I'haurem iniciat probablement a la població d'Olesa de Montserrat, cal agafar la carretera $C-55$, la qual es dirigeix cap al Nord, (cap a Manresa), fins arribar al trencall d'on neix la carretereta que condueix a l'antic Balneari de la Puda. En arribar a la cruillla es farà la present aturada, després de recórrer uns $3 \mathrm{Km}$ des del possible inici del recorregut a l'esmentada població d'Olesa de Montserrat.

En tot aquest trajecte, s'han anat trobant materials paleozoics, generalment recoberts per derrubis de pendent quaternaris, o per les terrasses del riu Llobregat; és a dir:: materials detrítics de l'Holocè. Així, en aquest recorregut ens hem situat plenament dintre e la Serralada Prelitoral Catalana, la sotsunitat més externa del Sistema Mediterrani. Entre els materials paleozoics que hem anat trobant predominen les psamites grises, així com els esquists i les pissarres (anomenades popularment amb el nom de llicorelles). En aquest indret, es troben gran quantitat de filons de QUARS, els quals tallen els materials paleozoics anteriorment esmentats. (fotografia 1). Molt sovint, aquests filonets es troben formant "boudins", (fotografia 2). 


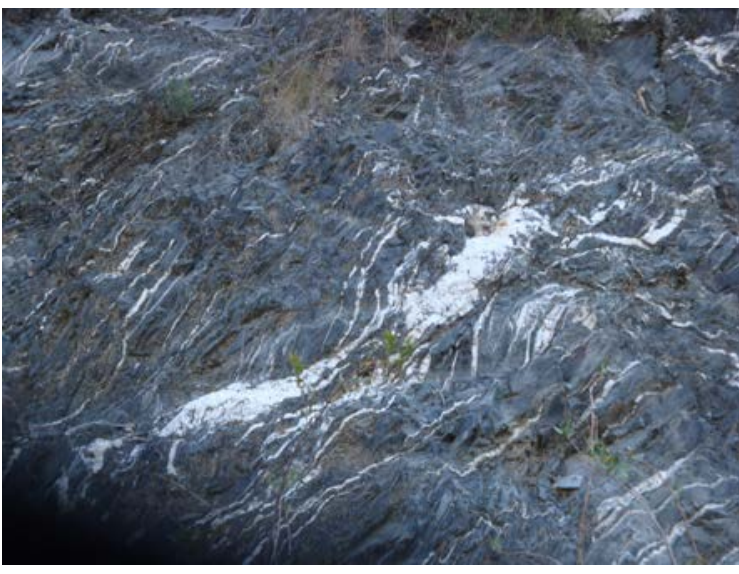

Fotografia 1. Filonets de QUARS entre els esquistos

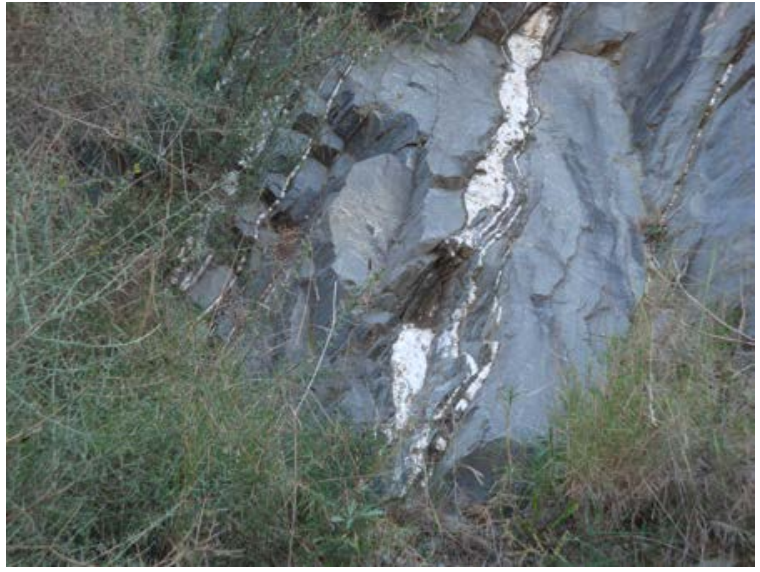

Fotografia 2. Boudinatge entre els filonets de Quars

Per altra banda, en aquest indret apareix una falla força inclinada, la qual talla als materials paleozoics. La falla es presenta amb una bretxa mineralitzada, trobant-se entre altres minerals primaris: PIRITA, ARSENOPIRITA, FLUORITA, BARITINA i QUARS, predominant el primer i el tercer. Tot i això, cal dir que a l'actualitat és força difícil trobar bones mostres, en trobar-se molt enlairat l'indret on apareixen.

Per d'altra banda, entre els minerals d'alteració es troben: GOETHITA (molt limonititzada), FERROHEXAHIDRITA, MELANTERITA i SIDEROTIL, entre altres minerals. Precisament, cap a les parts més altes, la falla es fa molt palesa a partir de l'oxidació dels sulfurs de ferro, deixant per sota de la mateixa una aureola d'alteració, mol ben notòria. (fotografia 3 i 4).
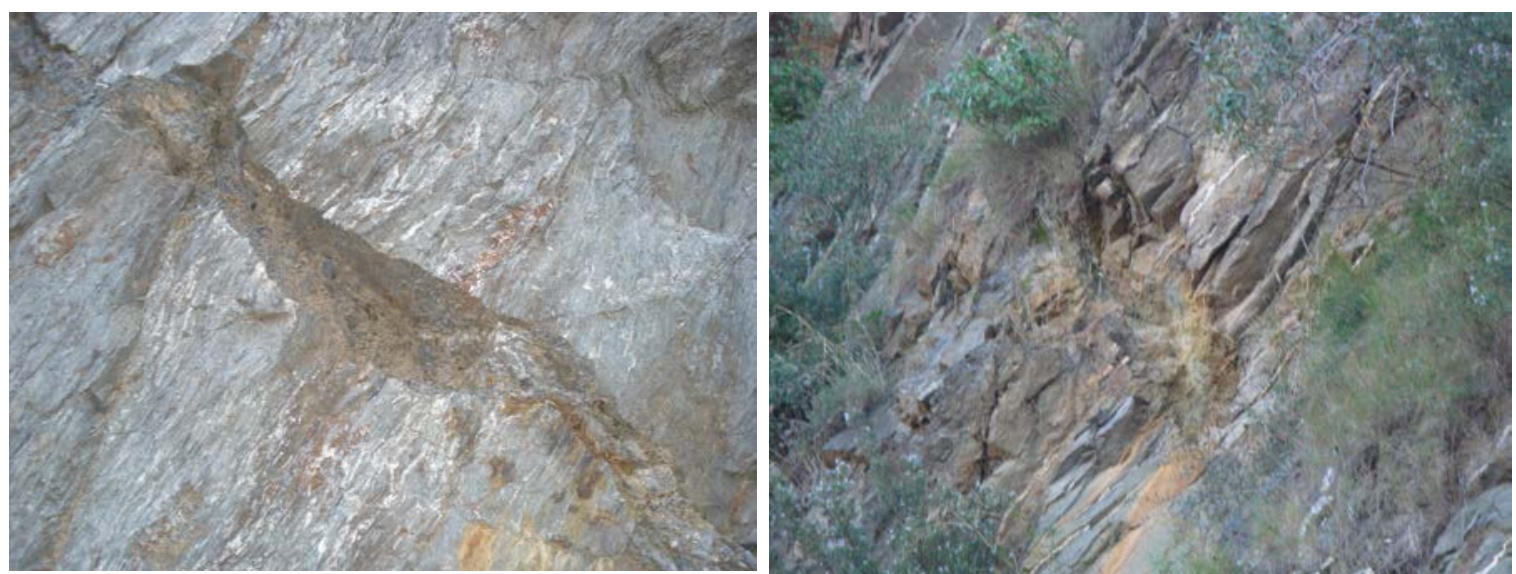

Fotografia 3. La falla mineralitzada i la bretxa de la Fotografia 4. Alteracions dels sulfurs de ferro del filonet mateixa

Per d'altra banda, sobre aquests afloraments dels materials paleozoics i de les mineralitzacions, es fa molt palesa la terrassa mitja del riu Llobregat. Aquests materials recents de I'holocè, es fan ben visibles a uns 20 - 30 metres per sobre de la carretera que es dirigeix cap el Balneari de la Puda, per on anem caminant. 


\subsection{Parada 2. Corriol de Sant Salvador de les Espases, extrem occidental de les agulles de Petintó, (terme municipal d'Esparreguera, comarca del Baix Llobregat, subcomarca del Baix Llobregat - Nord). (Full 392)}

Després de realitzar l'aturada anterior, cal fer un breu recorregut per la carretera de la Puda (d'uns 150 metres), per tal de trobar el sender que puja cap a Sant Salvador de les Espasses, remuntant inicialment el Torrent de l'Afrau. A uns 200 metres de l'inici i a uns 150 després de sobrepassar la via dels FFCC, farem una nova aturada. En total a uns 350 metres de la parada anterior.

En aquest recorregut haurem trobat afloraments dels materials paleozoics (de l'Ordovicià) de la Serralada Prelitoral Catalana. Sovint trobarem molts bons exemples d'esquistositat entre els materials paleozoics.

Per d'altra banda, a l'indret de l'aturada trobarem els nivells triàsics del Buntsandsteim, amb nivells de conglomerats verticals, formant uns vistosos "hock-backs", que sembles espasses. Aquest indret, forma part de les anomenades Agulles del Petintó, situant-se, al seu extrem occidental. (fotografia 5).

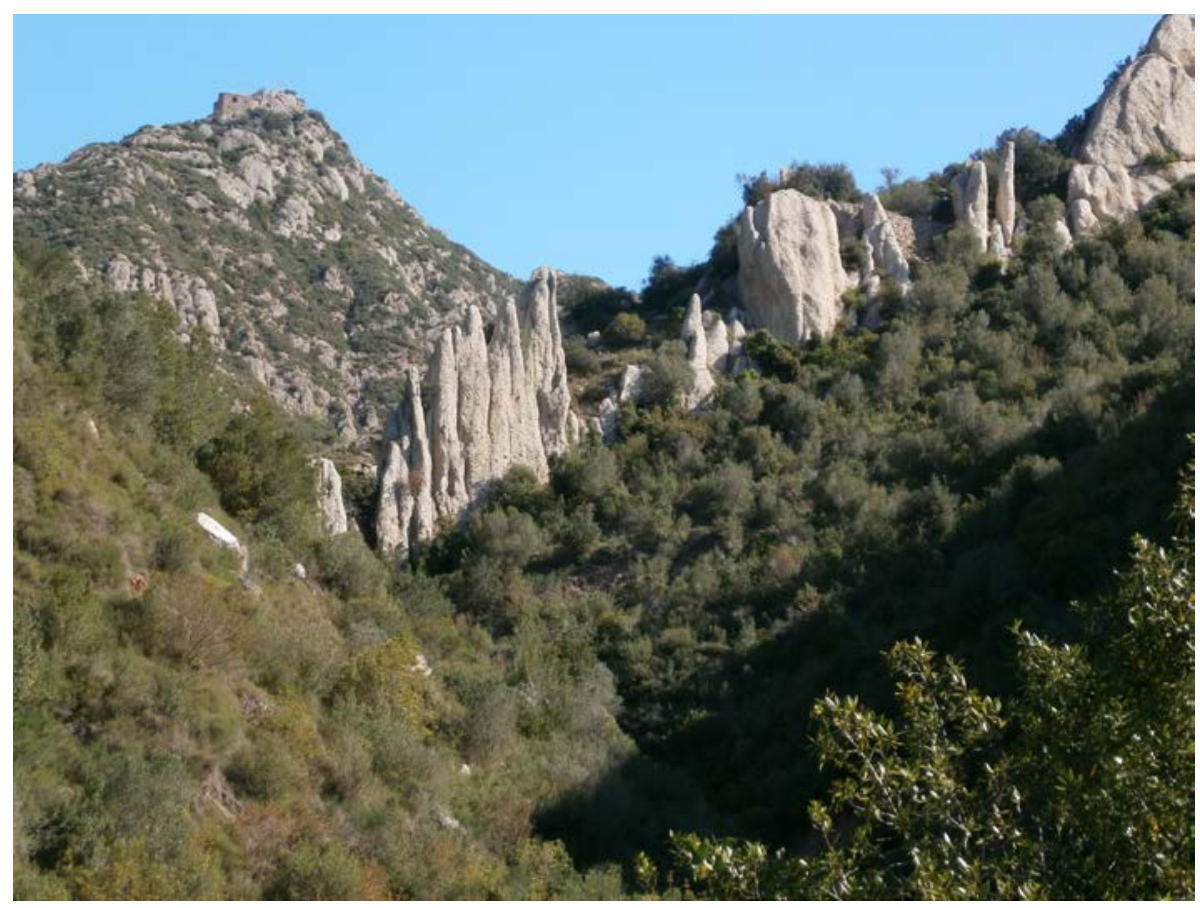

Fotografia 5. Nivells de conglomerats quarsosos del Buntsandsteim. Barranc de l'Afra. Al fons es pot veure Sant salvador de les Espasses, sobre conglomerats carbonatats cenozoics

Seguint cap amunt, per sobre d'aquests materials anirem trobant afloraments dels trams de gresos rogencs i calcolutites dels trams mitjos i superiors del Buntsandsteim (del Triàsic Inferior). Tot i així, a l'altra banda del torrent, cada cop es fan més palesos els afloraments dels nivells de calcàries i dolomies triàsiques del Muschelkalk Inferior, 
la qual cosa ens fa pensar en l'existència d'una possible falla que va seguint el Torrent de l'Afrau, per on discorre el camí ascendent.

\subsection{Parada 3. camí de sant salvador de les espasses, aiguabarreig del barranc de sant salvador i del barranc de l'afrau, (terme municipal d’Esparreguera, comarca del Baix Llobregat, subcomarca del Baix Llobregat - Nord). (Full 392)}

Després de realitzar l'aturada anterior, cal fer un altre breu recorregut a peu pel sender que puja cap a Sant Salvador de les Espasses, remuntant el Torrent de I'Afrau. A uns 100 metres de la parada anterior, en realitzarem una altra, aproximadament a l'aiguabarreig del barranc de ant Salvador i del barranc de l'Afrau.

En aquest breu recorregut, quasi sempre ascendint per un camí recentment arreglat, anirem trobant afloraments dels materials rogencs del Buntsandsteim, amb gresos i calcolutites rogenques. Sovint trobarem molts bons exemples de laminacions creuades entre les primeres roques esmentades. Per d'altra banda, també es fan palesos més amunt els afloraments de les calcàries i dolomies del Muschelkalk Inferior. Tanmateix, sovint haurem trobat blocs despresos d'aquestes roques pel costat del camí o al fons del barranc.

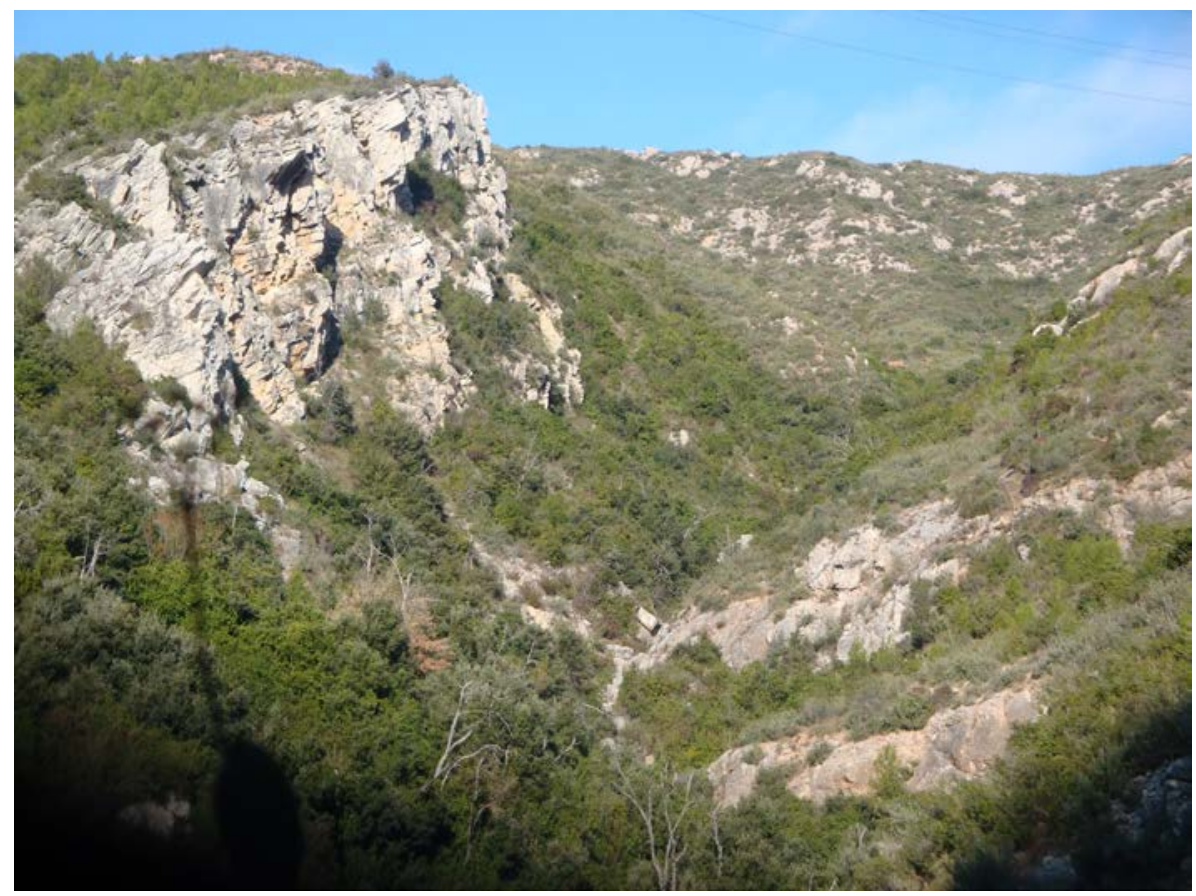

FOTOGRAFIA 6. Falla del Barranc de Sant Salvador

Des d'aquest indret, mirant cap a l'altre cantó del Torrent de l'Afrau, es fa palès el Barranc de Sant Salvador. En observar-lo es veu com a la vorera ponentina afloren els materials del Musckelkalk, mentre que a la vorera oriental ho fan uns nivells de gresos 
i conglomerats carbonatats que pertanyen al Cenozoic, probablement al Paleocè Eocè. És a dir, es va evident l'existència d'una fractura que posa en contacte els materials triàsics (del Musckelkalk) de la Serralada Prelitoral Catalana, amb els nivells cenozoics de la Depressió Geològica de l’Ebre. (fotografia 6).

Observant aquesta fractura, a l'esquerra (a ponent) es veuen els nivells carbonatats del Musckelkalk Inferior, apareixent per sobre d'ells un petit aflorament dels trams rogencs del Muschelkalk Mig (amb gresos i calcolutites rogenques). A I'altra banda del torrent, apareixen els materials terciaris del Paleocè i Eocè. Així, des de la nostra posició òptica dona la impressió de tractar-se d'una falla normal. Malgrat això, es tracta d'un encavalcament dels materials mesozoics del Triàsic sobre els cenozoics acabats d'esmentar, com es fa palès des d'altres indrets propers, mes ben situats en relació a la fractura.

\subsection{Parada 4. Camí de Sant Salvador de les espases, pas del barranc de l'Afrau, (terme municipal d’Esparreguera, comarca del Baix Llobregat, subcomarca del Baix Llobregat - Nord). (Full 392)}

Després de realitzar l'aturada anterior, cal fer un altre breu recorregut a peu pel sender que puja cap a Sant Salvador de les Espasses, remuntant el Torrent de l'Afrau. Poc després de realitzar la parada anterior, ens caldrà creuar el Barranc de l'Afrau, que hem estat remuntant. Ara, en aquest indret l'hem sobrepassat.

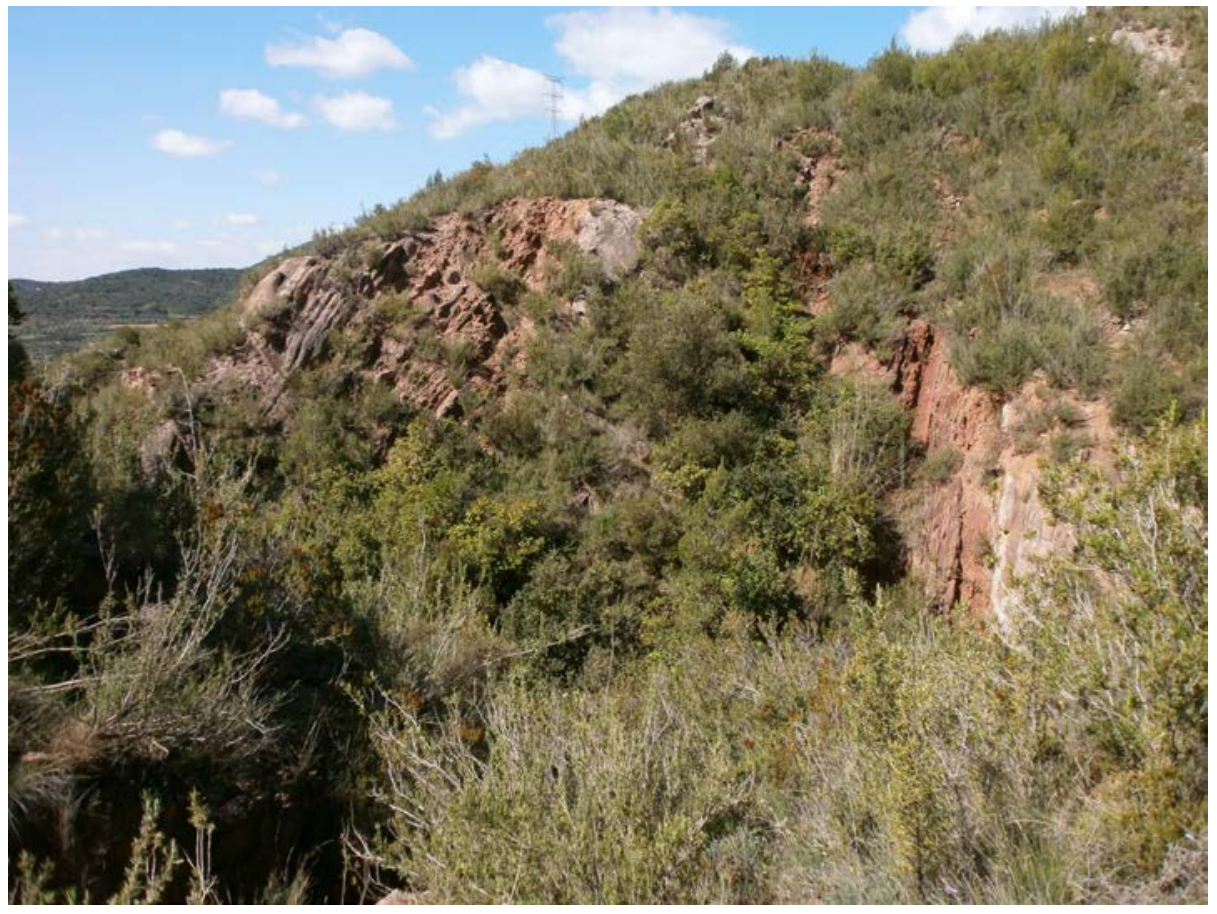

Fotografia 7. Un aspecte de la discordança progressiva 
En aquest indret, es fa clarament ostensible una discordança progressiva, entre els materials cenozoics del Paleocè. En efecte, podem veure com els inferiors, els situats a l'esquerra es troben inclinats (amb un cabussament invertit), mentre que els de la dreta es troben verticalitzats. (fotografia 7).

Tot i així, tots ells es troben encavalcats pels materials mesozoics del Triàsic Mig, del Muschelkalk. (fotografia 8).

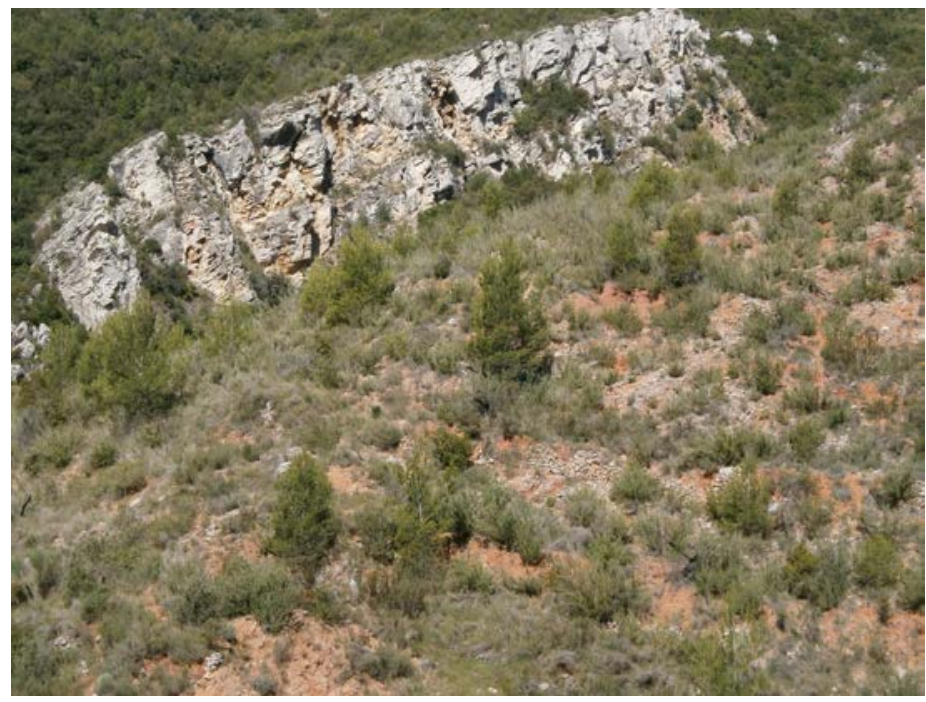

FOTOGRAFIA 8. Encavalcament dels materials cenozoics per les roques carbonatades del Muschelkalk

\subsection{Parada 5. Camí de Sant Salvador de les Espases, immediacions de l'avenc de Sant Salvador, (terme municipal d’Esparreguera, comarca del Baix Llobregat, subcomarca del Baix Llobregat - Nord). (Full 392)}

Després de realitzar l'aturada anterior, cal fer un altre breu recorregut a peu seguint pel sender que va pujant cap el Santuari de Sant Salvador de les Espases, remuntant ara el Torrent de Sant salvador. En arribar a un altre replà, a uns 150 metres de I'anterior, farem una nova aturada.

En aquest recorregut, hem continuat trobant afloraments dels materials cenozoics. Aquests es troben constituïts per trams de conglomerats, gresos i de calcolutites de tonalitats rogenques. Aquests materials pertanyen al Paleocè. A mida que anem pujant cap a Sant Salvador, els anem trobant cada vegada més detrítics, amb força trams de conglomerats.

Des d'aquest indret, es pot veure l'encavalcament dels materials carbonatats triàsics del Muschelkalk de les Roques de l'Afrau (situada a la dreta) sobre els terrenys cenozoics del Paleocè (situats a l'esquerra). (fotografia 9).

Per d'altra banda, en aquest recorregut s'ha fet palesa una possible fractura, que afecta als materials mesozoics triàsics del Muschelkalk. (fotografia 10). 
Els materials cenozoics marquen una clara discordança progressiva. Els de la dreta cabussen cap el Sud, mentre que els de la esquerra, ho fan cap el Nord. Per d'altra banda, l'aflorament carbonatat més proper encavalca als materials cenozoics (rogencs)

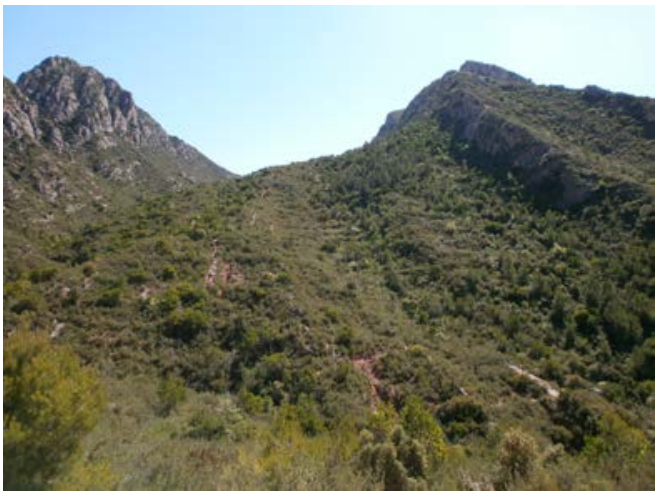

Fotografia 9. Encavalcament dels materials cenozoics per les roques carbonatades del Muschelkalk.

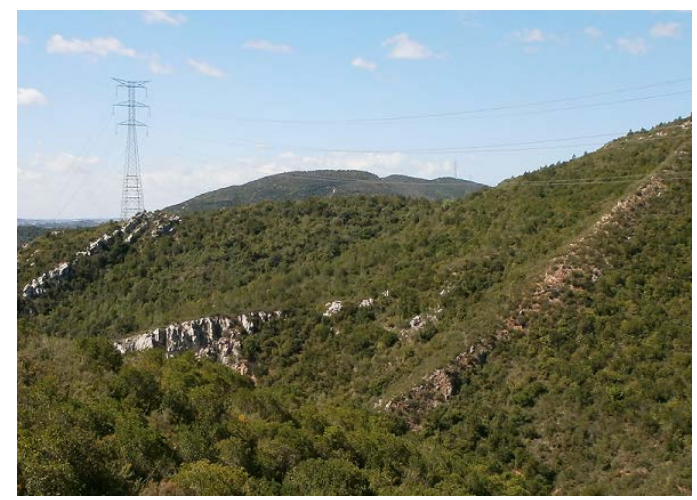

Fotografia 10. Possible fractura entre els afloraments de les roques carbonatades del Muschelkalk, entre els dos afloraments carbonats, pel coll que s'endevina.

\subsection{Parada 6. Sant Salvador de les Espases, (terme municipal d’Esparreguera, comarca del Baix Llobregat). (Full 392)}

Després de realitzar l'aturada anterior, cal acabar de pujar cap al Santuari de Sant Salvador de les Espasses. En aquest recorregut, hem continuat trobant els materials esmentats als recorreguts cap a les aturades anteriors. Així, haurem trobat afloraments dels materials cenozoics del Paleocè,. Aquests són els materials que es troben al Santuari, cada vegada ,més verticalitzats i més detrítics.

Des d'aquest indret, mirant cap al SE, es pot veure un relleu i una estructura molt similar a la que hem vist a l'aturada anterior, amb els nivells carbonatats triàsics encavalcant als cenozoics de la Serra de I'Hospici. També, des d'aquest indret mirant cap el NE, cap al Turo de la Sucarrada, es pot veure molt clarament la discordança progressiva. Així, els materials cenozoics, van atenuant la seva inclinació, des de les posicions més meridionals a les més septentrionals. (fotografia 11).

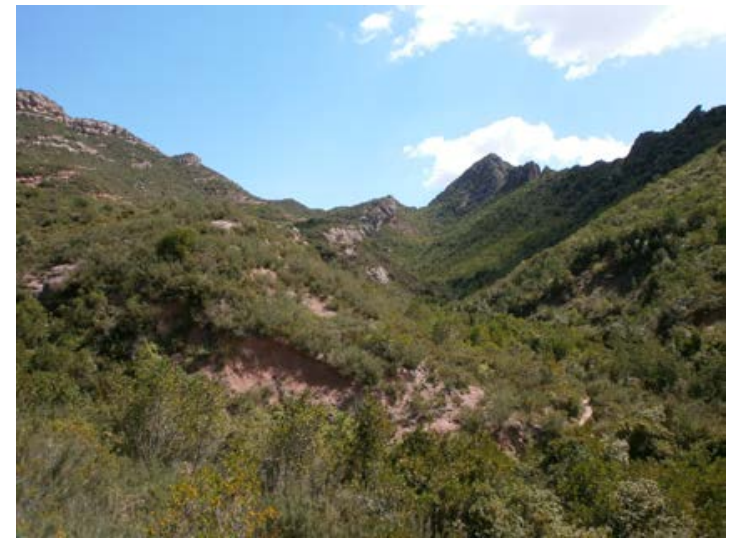

Fotografia11. Un aspecte de la discordança progressiva 


\subsection{Parada 7. Coll de Sant Salvador, (terme municipal d'Esparreguera, comarca del Baix Llobregat, subcomarca del Baix Llobregat - Nord). (Full 392)}

Després de realitzar l'aturada anterior, cal baixar des de Sant Salvador de les Espasses, anant cap a llevant. Poc després de deixar el Santuari, trobarem per l'esquerre un camí que es dirigeix cap a Can Tobella. Ens caldrà agafar-lo. Aquest camí anirà baixant cap el torrent de Sant Salvador. Després de travessar-lo, ens caldrà pujar cap el Coll de Sant Salvador. En arribar a aquest indret, farem una nova aturada. Així, haurem efectuat un recorregut proper a 1 $\mathrm{Km}$.

En aquest recorregut, hem anat trobant materials constituïts per alternances de gresos, conglomerats i calcolutites. Aquests materials, d'una clara tonalitat rogenca, son els que apareixen a l'indret de la present aturada.

Aquest indret, mirant cap al SE, és un bon lloc d'observació tant de la discordança progressiva com dels relleus de Sant Salvador de les Espasses. (fotografies 12 i 13).

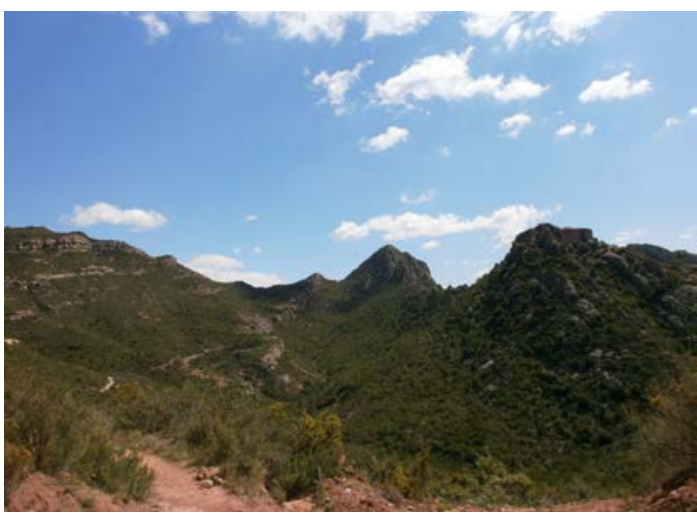

Fotografia 12. Un altre aspecte de la discordança progressiva, al Nord de Sant salvador de les Espases

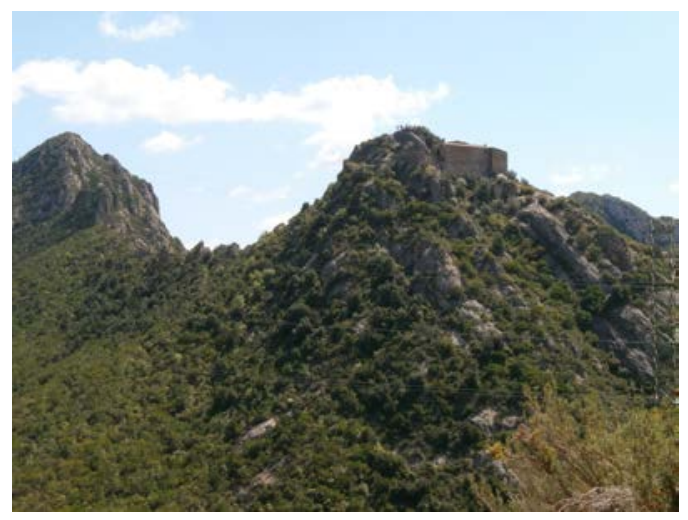

Fotografia 13. Un aspecte de Sant salvador de les Espases, del Coll de Sant Salvador

Per d'altra banda, des d'aquest indret, mirant cap al Nord i cap al NW, es pot gaudir d'una bona visió de Montserrat i del Pla del Bruixes. Tanmateix es poden veure els relleus triàsics de la Serra de Rubió, repartida entre els termes municipals de Collbató $\mathrm{i}$ d'Esparreguera.

\subsection{Parada 8 - condicional. Camí al Pla de les Bruixes, (terme municipal d'Esparreguera, comarca del Baix Llobregat, subcomarca del Baix Llobregat - Nord). (Full 392)}

Després de realitzar l'aturada anterior, cal baixar cap a Can Tobella, cap a ponent. Però en arribar a trobar el camí que va ascendint cap el Pla de les Bruixes, farem una nova aturada, a poc més de $1 \mathrm{Km}$ de l'anterior.

En aquest recorregut, hem anat trobant afloraments dels materials esmentats a les aturades anteriors. Aquests materials, amb nivells de gresos, conglomerats i calcolutites de tonalitats rogenques, pertanyen al Paleocè i a l'Eocè Inferior, segons els indrets. 
En aquest indret es fa palès l'aflorament d'uns travertins, situats entre els materials cenozoics. (fotografia 14).

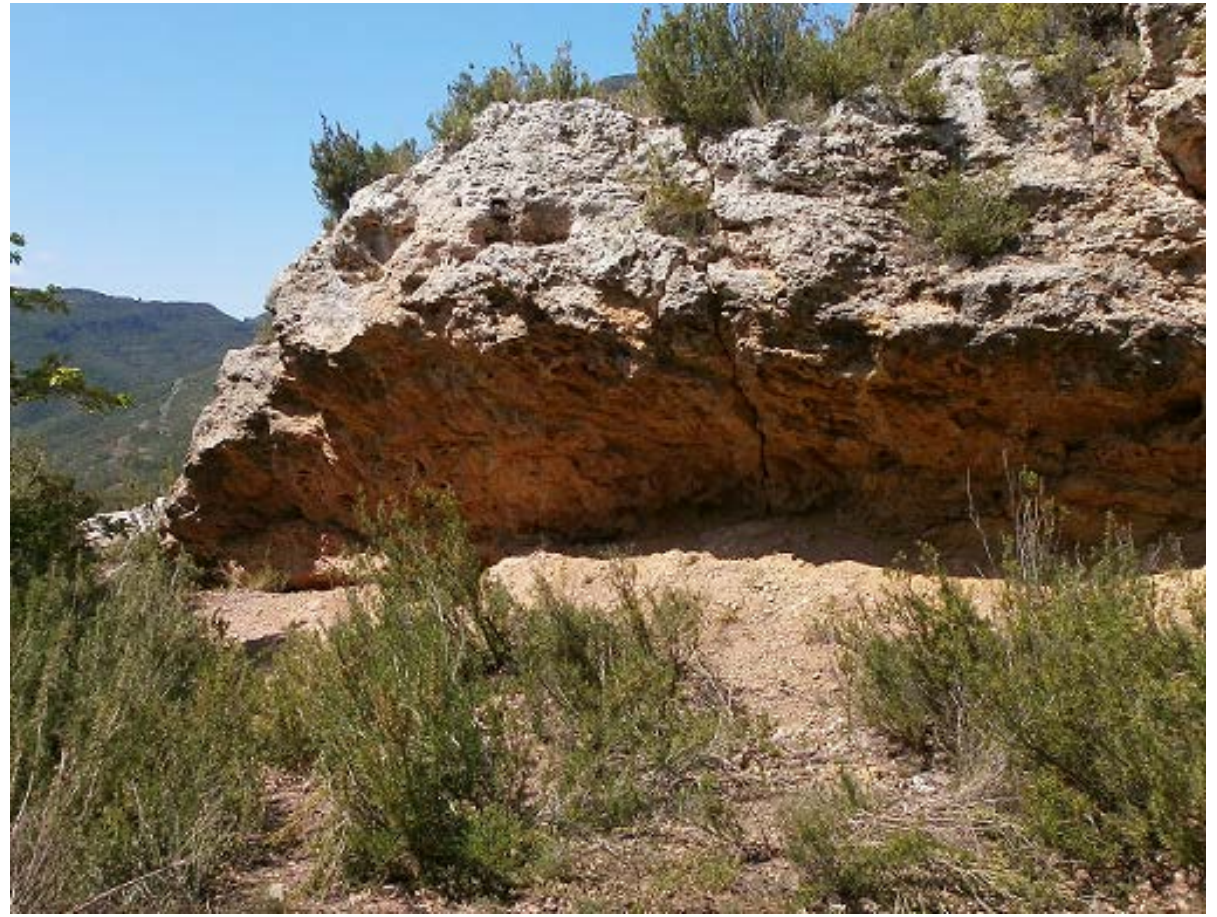

Fotografia14. Aflorament de travertins interestratificats, prop del camí al Pla de les Bruixes

\subsection{Parada 9. Coll de Can Tobella, (terme d'Esparreguera, comarca del Baix Llobregat, subcomarca del Baix Llobregat - Nord). (Full 392)}

Després de fer l'aturada anterior, cal seguir el camí (en molt bon estat) que condueix cap a la Can Tobella. A uns 200 metres de la parada anterior, caldrà seguir per un trencall que surt per la esquerra (en no tan bon estat de conservació). Aquest camí ascendeix lleugerament, per baixar després cap a la Puda. Prop d'aquest indret podem fer una nova aturada, a uns 500 metres de la parada anterior.

En aquest recorregut, haurem trobat afloraments dels materials cenozoics de l'aturada anterior. Fonamentalment, haurem vist trams de gresos i calcolutites rogenques (amb intercalacions de nivells de conglomerats i bretxes). Aquests materials pertanyen probablement a la Formació Cairat i a la Formació Mediona.

Per d'altra banda, des de l'indret on ara som, es pot veure (mirant cap el Nord) el Pla de les Bruixes, situat sobre Can Tobella. Al Pla de les Bruixes hi afloren nivells de conglomerats similars al de Montserrat, que veiem a l'altre canto del riu. Aquests materials formen part de I'anomenada Formació Montserrat. Des d'on som, dona la impressió que aquests materials tenen un cabussament gairebé horitzontal, en realitat es trobem inclinats cap el Nord, a l'igual que els de Montserrat (fotografia 15).

Fa uns anys, davant del perill d'esllavissades d'aquests materials, es van fer unes tasques de sanejament amb explosius, per tal d'evitar que els despreniments de blocs arribessin fins a Can Tobella. 


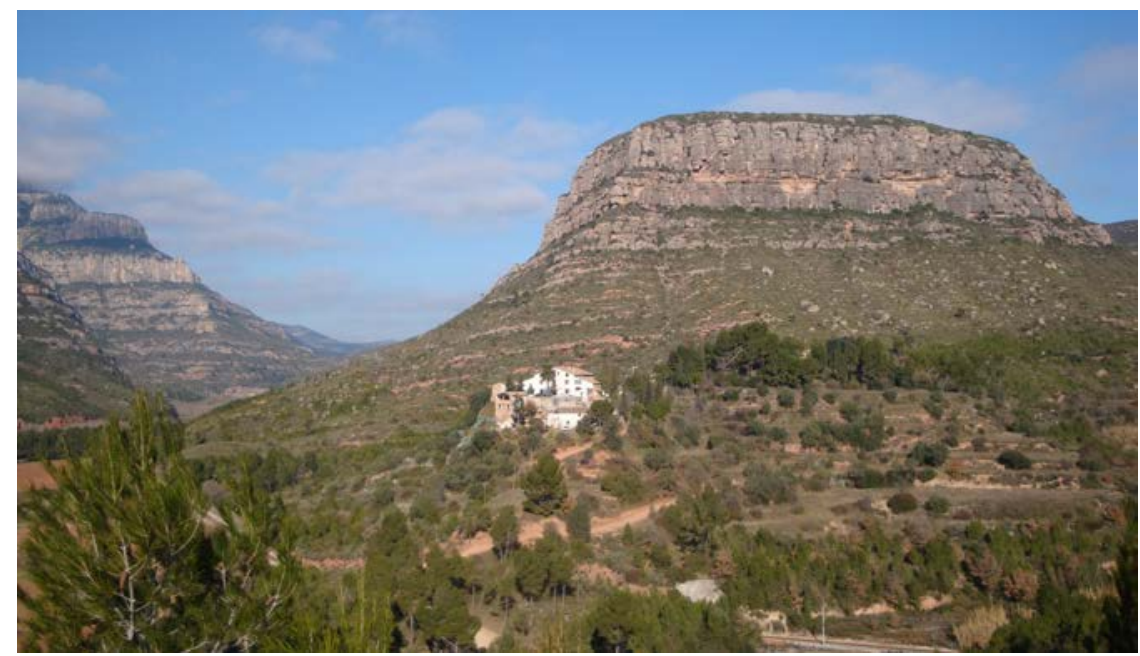

Fotografia 15. Cant Tobella i al seu darrera el Pla de les Bruixes. A l'altra banda del riu es pot veure Montserrat

Per d'altra banda, prop d'on som apareixen uns afloraments dels materials carbonatats del Muschelkalk, els quals encavalquen als cenozoics sobre els que estem situats ( fotografia 16).

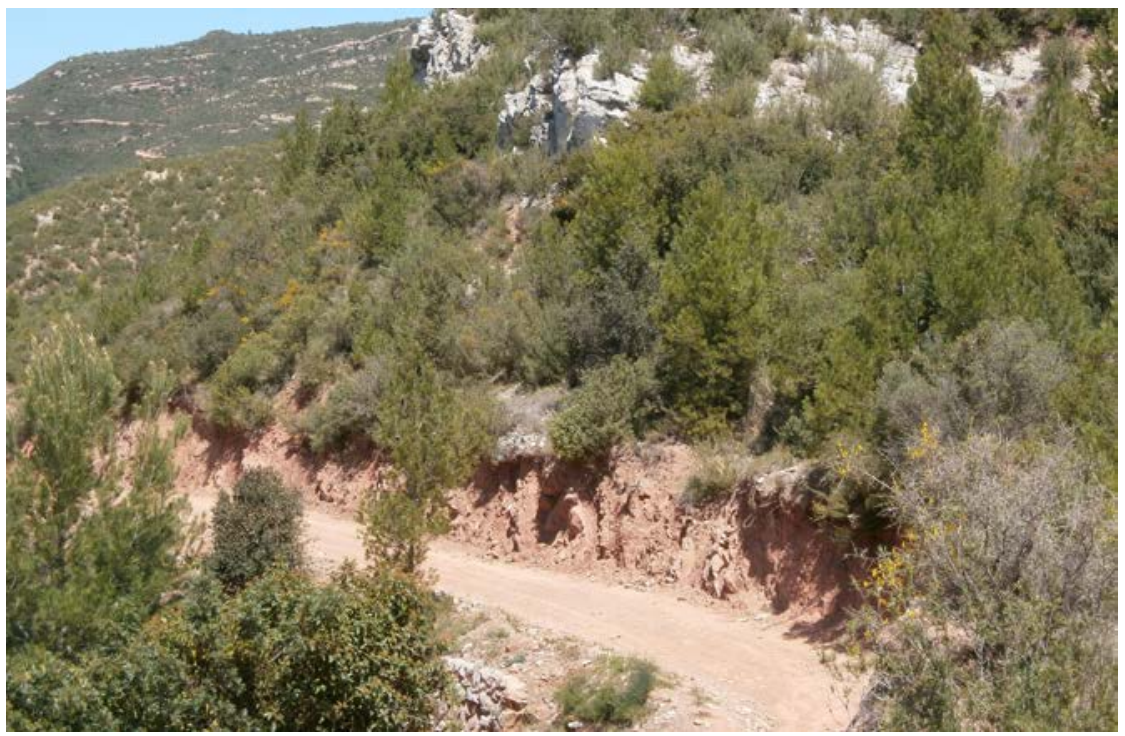

FOTOGRAFIA 16. Encavalcament dels materials carbonatats del Muschelkalk sobre els terrenys de gresos i calcolutites roges del Paleocè - Eocè Inferior, camí del Pla de les Bruixes

\subsection{Parada 10. Mirador del Cairat, (terme municipal d’Esparreguera, comarca del Baix Llobregat, subcomarca del Baix Llobregat - Nord). (Full 392)}

Després de realitzar l'aturada anterior, cal continuar pel camí. Aquest ara va descendent, fent ziga-zagues. En arribar a les immediacions del Cairat, podem fer una nova aturada, a poc més de $1 \mathrm{Km}$ de l'anterior. 
En aquest recorregut, hem trobat inicialment afloraments dels materials cenozoics esmentats a les aturades anteriors. Tot i així, més avall hem trobat afloraments dels materials carbonatats del Muschelkalk, en contacte per falla amb els anteriors, tot i que no I'hem arribat a trobar. Tanmateix, hem trobat uns afloraments d'uns nivells argilosos i guixosos, que probablement pertanyen al Keuper, fet que no hem arribat a veure clar. Després, en apropar-nos a l'indret de I'aturada, hem tornat a trobar els materials cenozoics, els quals es troben encavalcats pels anteriors. De fet el camí ha anat creuant el contacte entre els materials mesozoics i els cenozoics.

Per d'altra banda, a l'altra cantó del riu, haurem vist com afloren els materials del Muschelkalk encavalcant als terciaris de la Formació Cairat. (fotografia 17).

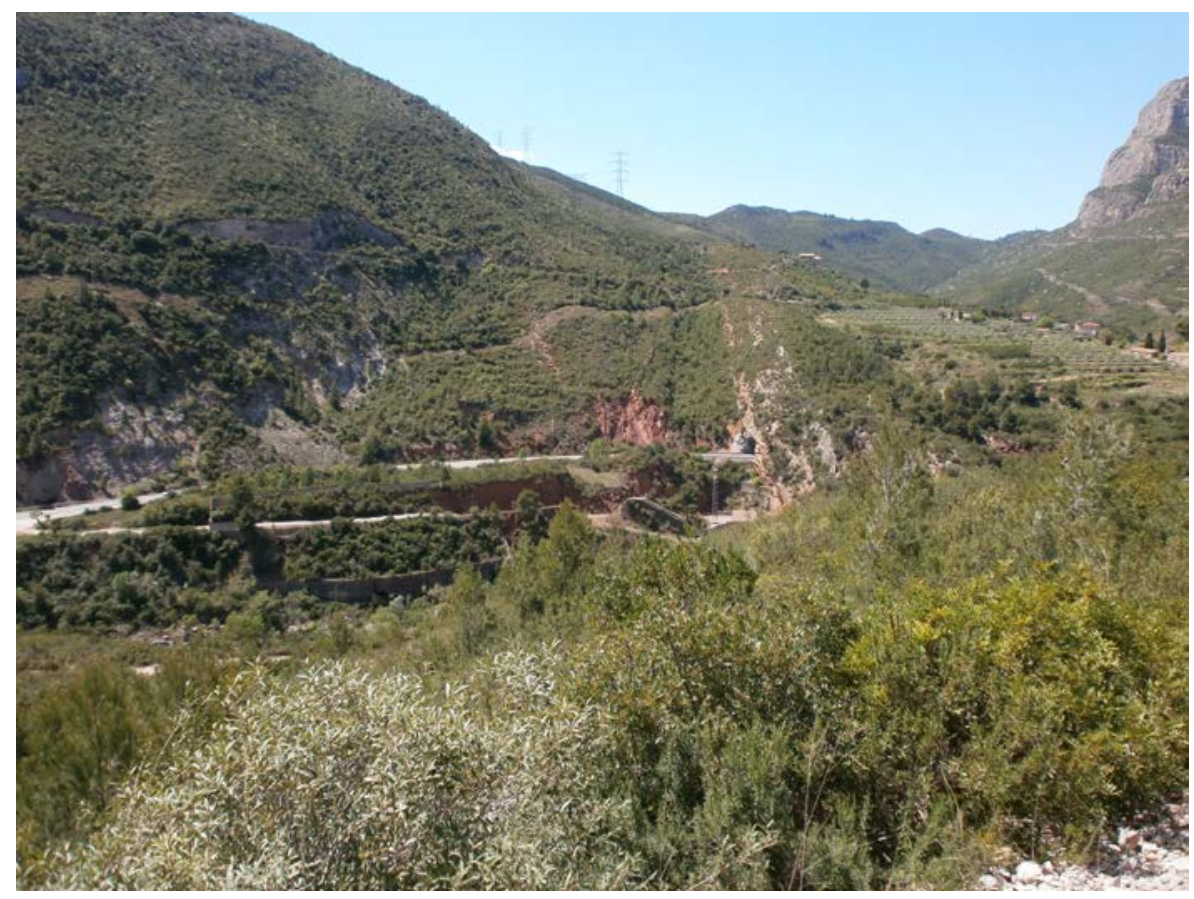

Fotografia 17. Encavalcament del Cairat. A dalt a l'esquerra hi ha les calcaries triàsiques del Muschelkalk. A baix a la dreta, els materials del Paleocè - Eocè Inferior, amb gresos i calcolutites rogenques

\subsection{Parada 11. Collet del camí de Can Tobella a la Puda, (terme d’Esparreguera, comarca del Baix Llobregat, Baix - Nord). (Full 392)}

Des de la parada anterior, cal seguir pel camí de terra que es dirigeix cap ara a la Puda de Montserrat. Poc abans de trobar (per l'esquerra) el camí que es dirigeix cap al Desert Carmelità, s'arribarà al Collet de Can Tobella. Una mica més enllà, caldrà fer una nova aturada, a menys de $1^{\prime} 45 \mathrm{Km}$ de l'anterior.

En aquest recorregut, hem anat trobant sempre els afloraments dels materials cenozoics del Cenozoic. Fonamentalment, aquests materials pertanyen a la Formació Cairat i a la Formació Mediona, respectivament del Paleocè i de I'Eocè Inferior. Així, haurem vist afloraments de nivells rogencs amb gresos (de vegades bretxes) i de calcolutites. Després, en aquest recorregut, a poca distància del Collet, en direcció cap al W, s'observa el contacte entre les calcàries del Muschelkalk Inferior i els nivells bassals del Paleocè, formats per gresos i 
margues. Cal destacar que entre aquests materials es va trobar restes fossilitzats de Bulimus Gerundensis. El contacte és realitza mitjançant una falla inversa, la qual pot permetre que els materials triàsics del Muschelkalk s'elevin per sobre dels del Paleocè, tractant-se d'una falla inversa. Així, es tracta d'un contacte entre els materials de la Serralada Prelitoral Catalana i els de la Depressió Geològica de l'Ebre. (fotografia 18).

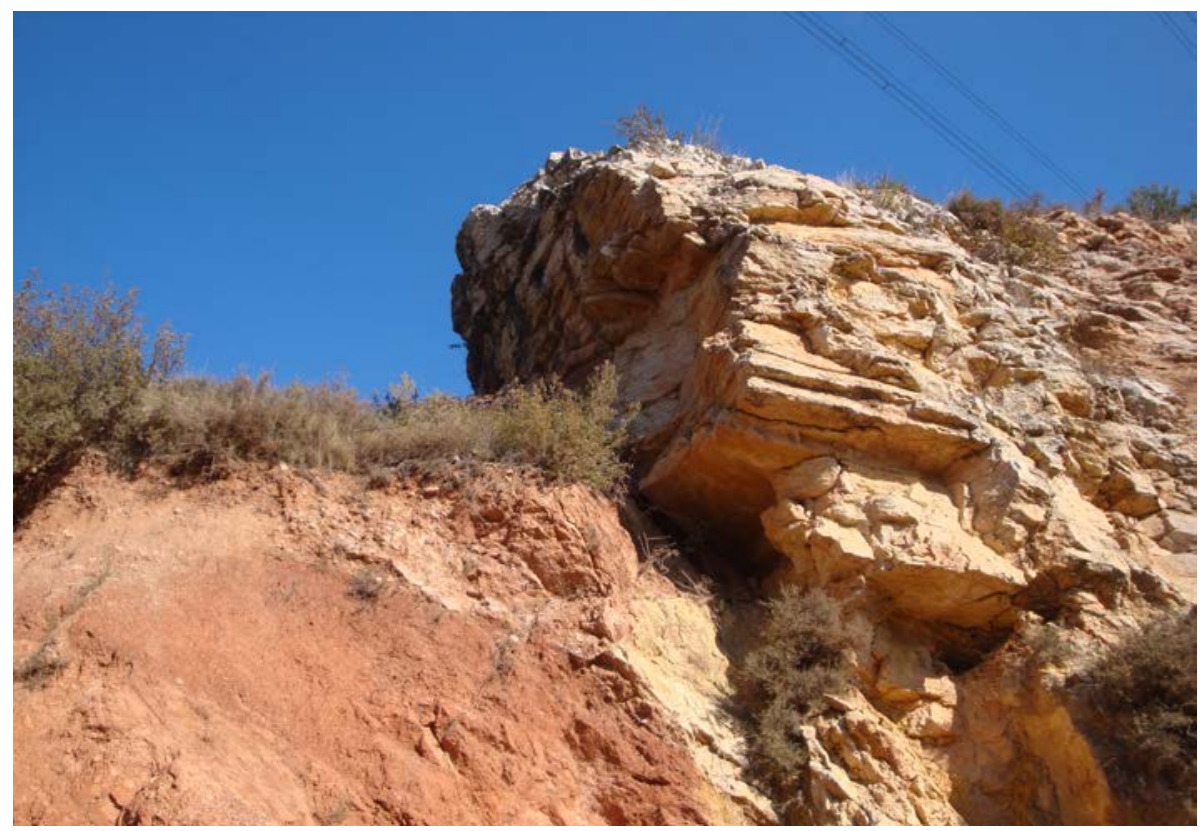

Fotografia 18. Un aspecte de la falla del Collet de Can Tobella. A l'esquerra hi ha els materials rogencs cenozoics del Paleocè Inferior (Formació Cairat). I a l'esquerra hi ha els terrenys carbonatats del Muschelkalk. La fractura es clarament inversa.

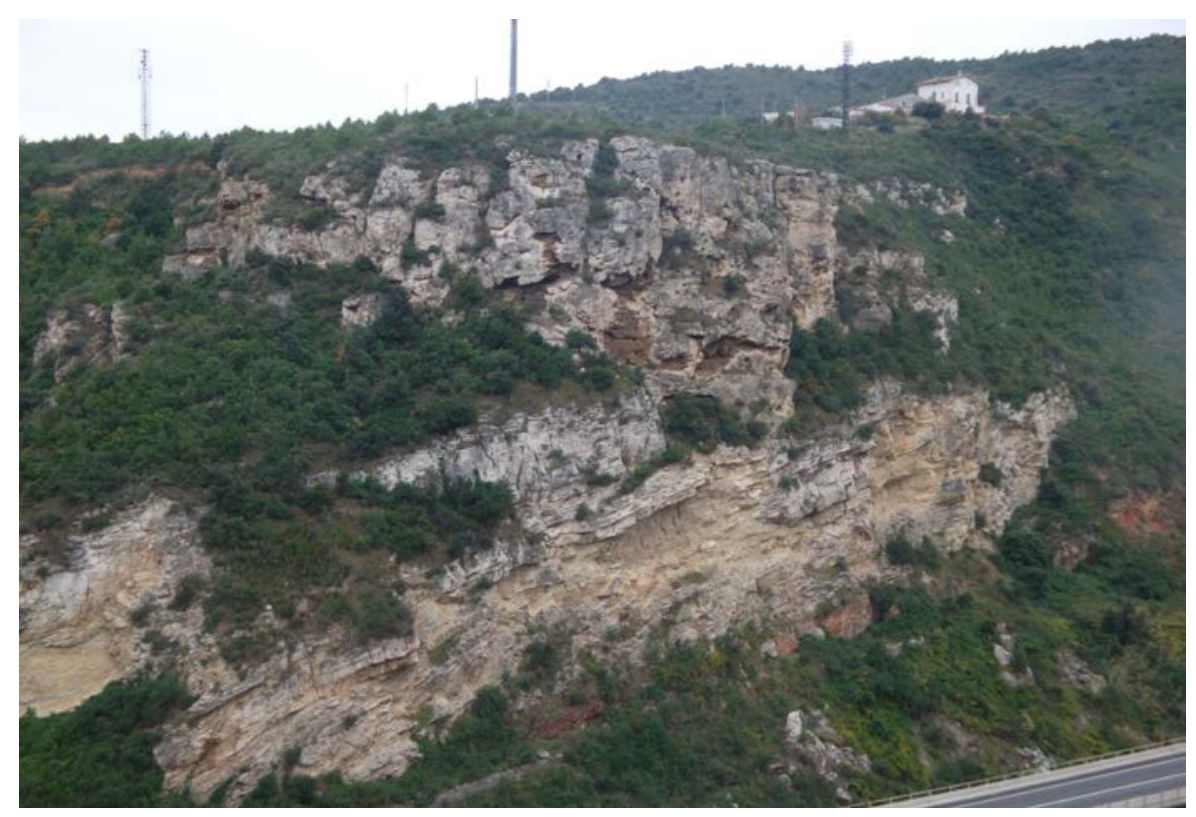

Fotografia 19. Aspecte de l'encavalcament a l'altra banda del riu. En primer terme hi ha el viaducte del Cairat. Aflorament dels travertins quaternaris, discordants sobre les calcàries triàsiques 
Per d'altra banda, mirant a l'altra banda del riu, es pot veure clarament el caràcter invers d'aquesta falla, en trobar-nos les calcàries per sobre dels materials rogencs (per on discorre el camí vell del balneari cap a Montserrat). Cal dir també, que en aquest indret situat a l'altra banda del riu Llobregat, és fàcil veure uns nivells de roques carbonatades clarament discordants amb les del Muschelkalk (també carbonatades). Es tracta d'un aflorament de travertins quaternaris, que sovint s'han denominat travertins de Can Paloma, per situar-se aquesta casa per sobre d'aquest aflorament. (fotografia 19).

\subsection{Parada 12. Balneari de la Puda, (terme d’Esparreguera, comarca del Baix Llobregat, subcomarca del Baix Llobregat - Nord). (Full 392)}

Després de realitzar l'aturada anterior, cal continuar pel camí que va baixant cap a l'antic Balneari de la Puda de Montserrat. En arribar-hi farem una nova aturada. Així, des de I'anterior haurem recorregut poc menys de 0’ $5 \mathrm{Km}$.

En aquest recorregut, hem anat trobant inicialment afloraments dels nivells carbonatats del Muschelkalk Inferior, tot i que es fan molt palesos (per sobre d'ells) els nivells dels gresos, calcolutites i guixos del Muschelkalk Mig. Inclús es veuen tascons d'aquests materials, de vegades en contacte amb els també rogencs del Buntsandsteim, que es troben més avall.

Després, prop del balneari, haurem trobat afloraments de les llicorelles paleozoiques de I'Ordovicià $\mathrm{i}$ del Silurià. Molt sovint aquests materials es troben recoberts per terrenys quaternaris d'origen detrític, procedents en bona part (o formant part) de les terrasses del proper riu Llobregat.

En aquest indret hi havia un antic balneari, en l'actualitat molt malmès. Cal dir que en els darrers anys s'ha intentat revitalitzar, sense cap mena d'èxit. Tot i així, forma part del Patrimoni Miner de la comarca del Baix Llobregat. (fotografies 20 i 21).

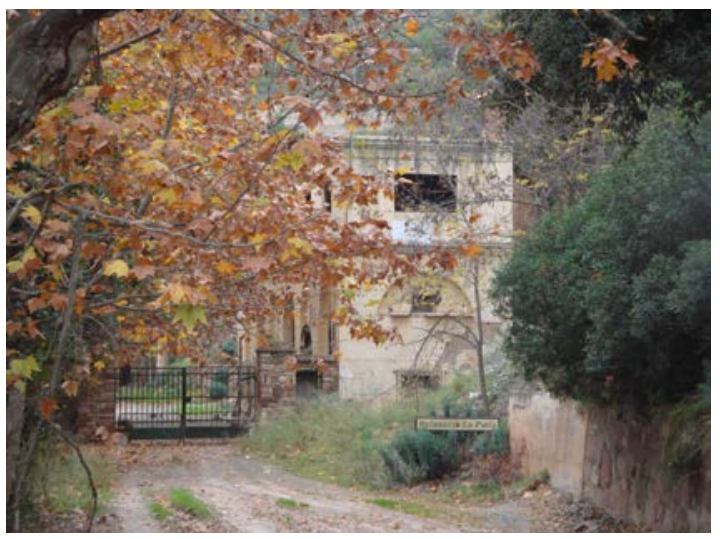

Fotografia 20. Entrada al Balneari de la Puda de Montserrat

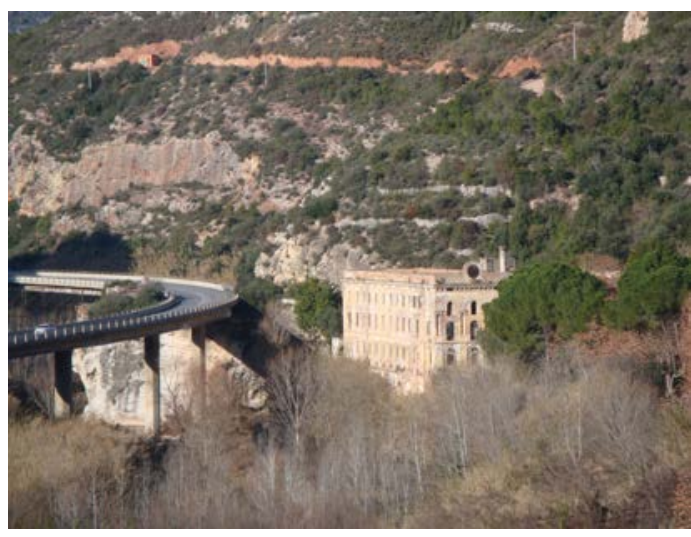

Fotografia 21. El balneari des del sender de Sant Salvador

També, cal dir que aquestes aigües tenen un marcat caràcter sulfhídric termal. Brollen a la bora del riu Llobregat. Aquesta deu forma part del Patrimoni Geològic de la comarca del Baix Llobregat. Mentre que les instal-lacions del vell balneari, formen part del Patrimoni Miner de la mateixa comarca. 
En aquest indret finalitza l'itinerari.

\section{BIBLIOGRAFIA}

CALZADA, S. i GAETANI, M. (1977).- Nota paleoecológica sobre M. Mentzeli (Brachiopada, Anisiense, Catalánides). Cuadernos de Geología Ibérica, vol 4, Pag. 157-158. Madrid

CALZADA, J. i JAIME, J. de (1978).- Algunos itinerarios geológicos desde Barcelona». Dep. Ciencias Col. San Antonio Abad, Escuelas Pias de San Antonio, Museo Geológico Seminario de Barcelona. Barcelona

LLOPIS, N. (1974).- Introducción al estudio de la morfoestructura de los Catalanides. Inst.Lucas Mallada. Consejo Sup.Inv.Científicas. Madrid

MARZO, M. i ANADON, P. (1977).- Evolución y características sedimentológicas de las facies fluviales basales del buntsandsteim de Olesa de Montserrat (Barcelona). Cuadernos de Geología Ibérica, vol. 4, Pg. 211-222. Madrid.

MASACHS, V. et altri (1981).- Itinerarios Geológicos. Centre d'Estudis Geològics de Manresa Caixa d'Estalvis de Manresa, 215 pag. Manresa

MATA-PERELLÓ, J.M. (1984).- Itinerari geològic per la riera de Sant Jaume, la Puda i Olesa (Serralada Prelitoral Catalana). Xaragall, $n^{\circ}$ 9, 31 pag. Manresa

MATA-PERELLÓ, J.M. (2001).- Itinerari de recerca geològica per la comarca del Baix Llobregat (termes municipals d'Olesa de Montserrat i d'Esparreguera). Inèdit. 8 pàgines. Manresa

MATA-PERELLÓ, J.M. (2005).- Sortida de recorregut geològic pel sud del Bages i pel Baix Llobregat Nord: des de Monistrol de Montserrat a Collbató, esparreguera i a Olesa de Montserrat. Inèdit. 10 pàgines. Manresa

MATA-PERELLÓ, J.M. (2012a).- Itinerari de recerca geològica per la comarca del Baix Llobregat: des d'Olesa de Montserrat a la Puda, al Cairat a l'Aeri de Montserrat i a Collbató. Inèdit, 10 pàgines. Manresa

MATA-PERELLÓ, J.M. (2012b).- Modificacions a l'itinerari de recerca geològica per la comarca del Baix Llobregat: des d'Olesa de Montserrat a la Puda, al Cairat i I'Aeri de Montserrat. Inèdit. 16 pàgines. Manresa

MATA-PERELLÓ, J.M. (2013).- Itinerari de recerca geològica per la comarca del Baix Llobregat: des de la Puda, al desert Carmelitià i al Cairat. Inèdit. 14 pàgines. Manresa

MATA-PERELLÓ, J.M. i CLIMENT I COSTA, F. (2010).- Coneix ... la Geologia des del Baix Llobregat. Edicions del Llobregat. Centre d'Estudis de la Comarca del Baix Llobregat. 51 pàgines. Sant Feliu de Llobregat.

SOLER, A. (1982).- La tectònica alpina a la Serralada Prelitoral Catalana en el sector comprés entre el Balneari de la Puda de Montserrat, Serra de Coll Cardús i la Serra d'en Font. Acta del Grup Autònom de Manresa, Inst, Cat. His. Nat. Manresa

VIRGILI, C, (1958).- El Triásico de las Catalánides. Bol. Inst. Geol. Mm. España (IGME). Madrid. 